\title{
Methyl Jasmonate Applications in Viticulture: A Tool to Increase the Content of Flavonoids and Stilbenes in Grapes and Wines
}

\author{
Gastón Gutiérrez-Gamboa ${ }^{1, *(D)}$, Roberto Mateluna-Cuadra ${ }^{2}$, Irina Díaz-Gálvez ${ }^{3}$, Nilo Mejía ${ }^{4}$ \\ and Nicolás Verdugo-Vásquez ${ }^{5, * \mathbb{D}}$
}

check for

updates

Citation: Gutiérrez-Gamboa, G.; Mateluna-Cuadra, R.; Díaz-Gálvez, I.; Mejía, N.; Verdugo-Vásquez, N. Methyl Jasmonate Applications in Viticulture: A Tool to Increase the Content of Flavonoids and Stilbenes in Grapes and Wines. Horticulturae 2021, 7, 133. https://doi.org/ 10.3390/horticulturae7060133

Academic Editor: Gianluca Allegro

Received: 19 April 2021

Accepted: 19 May 2021

Published: 5 June 2021

Publisher's Note: MDPI stays neutral with regard to jurisdictional claims in published maps and institutional affiliations.

Copyright: (C) 2021 by the authors. Licensee MDPI, Basel, Switzerland. This article is an open access article distributed under the terms and conditions of the Creative Commons Attribution (CC BY) license (https:// creativecommons.org/licenses/by/ $4.0 /)$.
1 Facultad de Ciencias, Escuela de Agronomía, Universidad Mayor, Camino La Pirámide Nº 5750, Huechuraba 8580000, Chile

2 Facultad de Ciencias Agrarias, Universidad de Talca, 2 Norte 685, Casilla 747, Talca 3460000, Chile; rmatelcu28@alumnes.ub.edu

3 Instituto de Investigaciones Agropecuarias (INIA), INIA Raihuén, Casilla 34, San Javier 3660000, Chile; idiaz@inia.cl

4 Instituto de Investigaciones Agropecuarias (INIA), INIA La Platina, Santa Rosa 11610, Santiago 8320000, Chile; nmejia@inia.cl

5 Centro de Investigación Intihuasi, Instituto de Investigaciones Agropecuarias (INIA), Colina San Joaquín s/n, La Serena 1700000, Chile

* Correspondence: gaston.gutierrez@umayor.cl (G.G.-G.); nicolas.verdugo@inia.cl (N.V.-V.); Tel.: +56-9-7994-2130 (G.G.-G.); +56-9-8391-2613 (N.V.-V.)

Abstract: Recently, the interest in methyl jasmonate (MeJ) has increased in viticulture due to its effects on the synthesis of phenolic secondary metabolites in grapes, especially of anthocyanins, flavonols, and stilbenes derivatives, naturally occurring or synthesized, in berries in response to $\mathrm{MeJ}$ application to grapevines. These metabolites help to define sensory characteristics of wines by contributing to their color, flavor and mouthfeel properties, and to derive potential beneficial health effects due to their consumption. This review offers an overview of the importance of these phenolic compounds in grape and wine quality, in association with the MeJ supplementation to grapevines, and also considers their natural biosynthesis in grapes. On the other hand, this review describes the adaptation mechanisms induced after the grapevine elicitation. In addition, this report addresses the effects of MeJ over other aspects of Vitis immunity and its association with phenolic compounds and summarizes the recently published reports about the effects of exogenous MeJ applications to grapevines on grape and wine quality.

Keywords: anthocyanins; defense mechanisms; elicitation; flavanols; flavonols; secondary metabolism; stilbenes

\section{Introduction}

The grapevine species (Vitis vinifera L.) is one of the important fruit crops in the world due to its economic and historical importance in the development of civilizations [1]. Grapes can be consumed as fresh fruits, raisins, juices, wines, and other processed products, and contain a varied range of phenolic compounds [2]. This brings with it beneficial potential for nutrition and human health $[3,4]$. In this way, phenolic compounds also contribute strongly to the sensory attributes of wine associated with quality such as color, astringency, and bitterness [5].

Since phenolic compounds have a positive impact on grapes' quality and nutritional value, different research, at the viticultural level, has been carried out in order to promote its biosynthesis in grapes [6]. In this way, some cultivation techniques have been studied to improve the phenolic content of grapes, such as the variety, rootstock, and trellis system selection, as well as bunch thinning and different irrigation strategies [7-11]. Viticultural strategies to stimulate the biosynthesis of polyphenols also include the application of plant 
growth regulators such as hormones and elicitors [6,12]. Regarding hormone applications, exogenous application of abscisic acid (ABA) on cv. 'Cabernet Sauvignon' grapevines has been shown to increase the total content of anthocyanins and phenols in grapes [13]. Similar results were obtained by Berli et al. [14] after exogenous applications of ABA to 'Malbec' cultivated at an altitude of $1450 \mathrm{~m}$. In this sense, field studies using ABA applications to grapevines showed a higher expression of $V v M Y B A 1$ and $V v M Y A B 2$ transcription factors (members of a gene family, found in animals and plants, named after the homonymous gene in the avian myeloblastosis virus) that participate in the regulation of biosynthetic genes chalcone isomerase, flavanone 3-hydroxylase gene, dihydroflavonol 4-reductase, and anthocyanidin 3-O-glucosyltransferase of the anthocyanin pathway in grapes, and, in turn, result in an increased accumulation of anthocyanins [15]. On the other hand, the application of brassinosteroids to cv. 'Red Globe' gave rise to an increase in berry color and in the synthesis of dihydroxylated anthocyanins, which are responsible for the red and pink color of the grapes [12].

Elicitors are defined as compounds that, when applied to a plant species, induce the activation of enzymatic metabolism to synthesize secondary metabolites in their plant tissues [16]. It is commonly known that phenolic compounds can be synthesized in response to different biotic and abiotic inducers [17]. In this sense, elicitors are molecules capable of stimulating the defense mechanisms of plants, including the activation of several secondary biosynthetic pathways such as the one that leads to the synthesis of phenolic compounds [16]. Among the chemical-type elicitors, methyl jasmonate (MeJ) can act as a signal molecule and is involved in inducing several defense mechanisms in plants by triggering the synthesis of a wide range of secondary metabolites $[18,19]$. In this sense, jasmonates participate in different oxidative and physiological responses after an abiotic stress event since they play a key role in various signaling processes between plant cells [20]. For these reasons, the MeJ has been the subject of study for the last years in viticulture, mainly due to its contribution to the synthesis of phenolic compounds in grapes, especially anthocyanins, flavonols, and stilbenes [21-23].

Based on the mentioned above, the aim of this review is to offer an overview of the use of MeJ in viticulture with emphasis on its effect on phenolic compounds synthesis in grapes. This review also aims to propose alternative guidelines for the development of future research in this area.

\section{Biosynthesis and Role of Phenolic Compounds in Grapes}

Based on the primary chemical structures of hydroxybenzenes, phenolic compounds can be classified into flavonoid and nonflavonoid compounds $[3,13,17,22]$. The most abundant flavonoids found in grapes include anthocyanins, flavonols, and flavanols [17]. Hydroxycinnamic and hydroxybenzoic acids, volatile phenols, and stilbenes are nonflavonoid compounds. Recent studies have been shown that anthocyanins, flavonols, flavanols, and stilbenes are important elicitor activity markers that are synthesized after the affection of a pathogen in the plants $[14,17,18]$. Flavonoid and nonflavonoid compounds are synthesized from phenylalanine through the phenylpropanoid synthesis pathway [24]. Phenylalanine, for its part, is a product of the shikimic acid pathway, which relates the metabolism of carbohydrates to the biosynthesis of aromatic amino acids and other secondary metabolites $[17,25]$.

The anthocyanins are water-soluble pigments responsible for the red color and its tonality variations in grapes and red wines. Recently, it has been demonstrated that these compounds also can contribute to the astringency and bitterness of grapes and wines [5]. The enzyme UDP-glucose:flavonoid 3-O-glucosyl transferase (UFGT) catalyzes the glycosylation of both anthocyanidins and flavonols [26]. In colored varieties, anthocyanins accumulation in grapes begins in veraison, concomitantly with the activation of the UFGT enzyme [27]. Firstly, only glycosides from dihydroxylated anthocyanins, such as cyanidin and peonidin accumulate in grapes and, subsequently, trihydroxylated anthocyanins, such as delphinidin, petunidin, and malvidin are accumulated [27]. The acylated anthocyanins 
are present in most of the grapes harvested from red varieties, probably due to the presence of the anthocyanin acyltransferase enzyme [17]. These anthocyanins are synthesized in the cytoplasm and accumulate in the vacuoles in red varieties, where they are stored as colored coalescences called anthocyanin vacuolar inclusions [17].

Flavonols contribute to the yellow color of grapes and wines [28]. These compounds also may contribute to wine astringency [29]. Flavonols are present only in grape skins, and there are no publications showing that these compounds have been detected in the seeds or in the pulp of the grapes [27,30]. These compounds are also present in shoots, tendrils, inflorescences, anthers, and leaves [30]. The synthesis of flavonols is related to the expression of genes that encode the enzyme flavonol synthase, which is activated in two key periods in grapes, the first around flowering and the second during berry ripening [30]. The lack of expression of the flavonoid enzyme $3^{\prime}, 5^{\prime}$ hydroxylase in white grapes restricts the presence of quercetin, kaempferol, and isorhamnetin derivatives, while red grapes also contain derivatives from myricetin, laricitrin, and syringetin [17]. Flavonol concentration is increased in response to high sunlight exposure before the veraison stage, which is induced by the MYB family transcription factor genes [31].

Flavanols are primarily responsible for the bitter taste and the astringency of grapes and wines and contribute to color stability in aged wines [5]. The synthesis of flavanols in the seeds occurs after the fruit set and reaches a maximum level close to the veraison stage [32]. The flavanol and flavonol contents of grape skins are high in flowering and their accumulation continues from the fruit set until one or two weeks after veraison [27,32]. However, there is recent evidence that flavanols resume synthesis 45 days after veraison [33]. The seeds contain shorter proanthocyanidin polymers, presenting similar levels of catechin and epicatechin subunits, while in the skins, the proanthocyanidin polymers are longer, being composed mainly by epicatechin subunits [34].

Stilbenes have a potential for the prevention and treatment of different diseases, including cancer, due to their antioxidant, cell death activation, and anti-inflammatory properties [35]. Nonflavonoid phenolic compounds are found in all higher plants, but only a few plant species produce stilbenes [36]. Stilbene synthase (STS) and chalcone synthase (CHS) are closely related enzymes since they specifically modulate the biosynthesis of flavonoids and/or stilbenes [17]. In this sense, CHS may compete with STS for the biosynthesis of phenolic compounds, and it has been shown that the decrease in the ability of grapes to synthesize stilbenes in response to UV radiation observed after the beginning of grape ripening, may be a consequence of the concomitant increase in anthocyanin accumulation in grapes [37]. The main stilbenes found in grapes are cis- and trans-resveratrol $\left(3,5,4^{\prime}-\right.$ trihydroxystilbene), resveratrol-3-O- $\beta$ - $d$-glucopyranoside (piceid), piceatannol $\left(3,4,3^{\prime}, 5^{\prime}-\right.$ tetrahydroxy-trans-stilbene), and resveratrol dimers (viniferins) $[17,18,37]$. Hopeaphenol, resveratroloside, resveratrol-4'-O- $\beta-\alpha$-glucopyranoside, and resveratrol di- and triglucoside derivatives are isomeric and glycosylated forms of resveratrol and piceatannol that have also been identified in trace amounts in grapes [17].

\section{Elicitation Resistance Mechanisms}

Jasmonates (JAs) are plant hormones that play an important role in regulating plant development, including root growth, stamen development, flowering, pollen fertility, and leaf senescence [38]. Methyl jasmonate (MeJ) is derived from jasmonic acid (JA), and the reaction is catalyzed by S-adenosyl-L-methionine:jasmonic acid carboxyl methyltransferase [39]. JAs are essential for the activation of defense mechanisms in plants in the short term and are involved in the inherited resistance as well [40,41]. JAs may regulate the growth and defense of plants, but even though they activate plant defense mechanisms, JAs inhibit plant growth [38,42]. JAs are synthesized from $\alpha$-linolenic acid in the plastid membrane lipid by lipase in chloroplasts $[43,44]$. Recently, it has been demonstrated that two abscisic acid-responsive plastid lipase genes are involved in jasmonic acid biosynthesis in Arabidopsis thaliana [45]. Subsequently, 12-oxo-cis-10,15-phytodienoic acid (OPDA) is first exported from the plastid and then imported into the peroxisome for subsequent metabolic 
conversions [24]. OPDA is converted to 3-oxo-2-(cis-2'-pentenyl) cyclopentane-1-octanoic acid (OPC-8:0) by OPDA reductase, and then, OPC-8:0 is activated by a carboxyl-CoA ligase and converted to (+)-7-isojasmonic acid by three rounds of $\beta$-oxidation [24]. JASMONATE RESISTANT 1 (JAR1) encodes an ATP-dependent JA-amido synthetase that conjugates JA to isoleucine (JA-Ile), resulting in the active isomer, which is inactivated in their trans form [46-49]. However, studies suggested that the rapid increase in JA-Ile mediated by the JAR1 enzyme plays only a minor role in transcriptional modulation of genes induced by mechanical wounding [50].

JASMONATE-INSENSITIVE 1 encodes an MYC transcription factor (member of a gene family, found in animals and plants, named after the homonymous gene in the avian myelocytomastosis virus) that is essential to control the response of JA-inducible genes [51]. JA-Ile-responsive gene expression is regulated by the transcriptional activator MYC2 that interacts physically with the jasmonate ZIM-domain (JAZ, jasmonate zincfinger inflorescence meristem-domain) repressor proteins [52]. Transcriptional repression involves a class of proteins called corepressors that link transcription factors to chromatin remodeling complexes or TOPLESS (TPL, named for being responsible for a mutant that forms apical roots rather than buds in the embryo) corepressor, which plays a key role in hormone signaling and development [53]. The JAZ proteins recruit the Groucho/Tup1-type (named after the homonymous gene Groucho identified in Drosophila or Tup1 from yeast) co-repressor TPL and TPL-related proteins through the Novel INteractor of JAZ (NINJA) adaptor protein [52,54]. NINJA acts as a transcriptional repressor of which the activity is mediated by a functional TPL-binding Ethylene-responsive element-binding factorassociated amphiphilic repression (EAR) repression motif [52]. Therefore, both NINJA and TPL proteins function as negative regulators of jasmonate responses [52]. JAZ proteins have been reported to be degraded in a proteasome-dependent manner following a jasmonate treatment but were stabilized in the coronatine-insensitive1 (coi1) coi1-1 background [55]. COI1 is an F-box, part of the degradation SCF complex (named after their main components, Skp I, Cullin, and an F-box protein), suggesting that Skp1/Cullin1/F-box protein COI1 was responsible for ubiquitinating the JAZ proteins [55] in the jasmonate perception pathway.

Exogenously applied elicitors in plants produce a series of defense responses in plant tissues such as priming and/or pattern-triggered immunity (PTI) [56]. This can provoke a hypersensitive response in the plant and consequently certain levels of protection against a pathogenic attack [56]. Priming is defined as the mechanism of activation of the immune system of plants that, without generating stress, can reduce different stresses of the biotic and abiotic type [57]. This resistance mechanism differs from the induction generated in response to pathogen recognition [56]. Unlike the induction by exogenous use of elicitors, induction of resistance against a pathogen can cause an expression of the resistance mechanism to become much more costly for the plant, proportional to the degree of the incidence and the severity of the disease [58].

The epigenetic mechanisms involved in the priming effect produce modifications of histones (by methylation, acetylation, sumoylation, and phosphorylation) and of chromatin, as well as changes in DNA methylation, which has a significant impact on the functionality of the transcription factors WRKY6, WRKY22, WRKY29 and WRKY53 (transcription factors that contain an invariant WRKY amino acid sequence at the N-terminus) that regulate several responses to biotic and abiotic stress [59-61].

Once the mechanisms associated with PTI are induced by exogenous application of elicitors, plants produce reactive oxygen species and a stronger oxidative burst than that which occurs after pathogen attack, activating mitogen-activated protein (MAP) kinase pathways and stimulate the pathways of salicylic acid (SA), jasmonic acid (JA), and abscisic acid (ABA) [56,57]. Callose deposition, a plant-based polysaccharide, which is related to ABA production, has been shown to produce in plants treated with elicitors [57]. Elicitors may also induce the expression of the phenylalanine ammonium lyase (PAL) enzyme that is required for the production of SA precursors [62]. 
The resistance process mediated by the accumulation of SA is called systemic acquired resistance, and it is based on the induction of secondary metabolic pathways, resulting in a greater synthesis of phenolic compounds $[63,64]$. SA acts by inducing (1) pathogenesisrelated proteins ( $P r$ genes), such as glucanases, peroxidases, and chitinases, which may contribute to plant resistance by hydrolysis of the pathogen's cell wall; (2) an oxidative burst that triggers the activation of phytoalexins with antifungal properties; and (3) the phenylpropanoid synthesis pathway after PAL activation, leading to the formation of phytoalexins, lignins, and SA [64].

Similarly, gene-related $\operatorname{Pr}$ genes, especially $\operatorname{Pr}-1, \operatorname{Pr}-2$, and $\operatorname{Pr}-5$ are also activated after the application of elicitors $[65,66]$. Both the priming effect and the activation of defense mechanisms after exogenous application of elicitors can lead to a reduction in the incidence and severity of the disease when occurs [56,67]. Indeed, MeJ treatments improved the levels of Pr-1 in leaves of Vitis quinquangularis, but this response was weaker than the ethephon (an ethylene releaser) and SA applications [68]. In addition, MeJ applications enhanced the accumulation of pathogenesis-related type proteins in cell cultures of the 'Gamay' variety [69]. However, in 'Mourvèdre' cell cultures, MeJ decreased the levels of some proteins such as pathogenesis-related protein 1, lysozyme M gen domain-containing glycosylphosphatidylinositol GPI-anchored protein 1, cationic peroxidase, and glycerophosphoryl diester phosphodiesterase but increased the levels of new gene products such as heparanase, $\beta-1,3$ glucanase, reticulin oxidase, and peroxidase IV, all of which could be used as potential biomarkers in the grapevine defense responses [70].

\section{Methyl Jasmonate (MeJ) Effects on Grape and Wine Quality}

Recently, as is shown in Table 1, the study of the foliar application of MeJ to grapevines has increased due to its positive effects on the synthesis of phenolic compounds in grapes $[18,64,71,72]$. The application of elicitors in viticulture, mainly jasmonates, induces the activation of enzymes involved in the synthesis of phenolic compounds [64,73]. Preliminary studies showed that the foliar application of MeJ to the grapevines allowed the increase in the anthocyanin and flavonol contents in grapes, improving the color characteristics of the wines, compared to the control samples [74-76]. More recent studies have reported that the foliar application of this elicitor to Tempranillo grapevines increased the anthocyanin and stilbene contents in grapes and wines, compared to control (Tables 1 and 2), and also enhanced the concentration of flavonols in the produced wines [23,77]. Probably, the differences obtained in the grapes were not the same as in the wines since, in general, for research purposes, the grapes are vinified under similar conditions, despite the fact that they have a different oenological potential due to the effects of MeJ treatments performed in the vineyard. On the other hand, it was reported that the concentration of trans-piceid increased in all the grape and wine samples after the foliar application of MeJ to Tempranillo grapevines. [23]. MeJ application to 'Graciano' and 'Garnacha' improved the phenolic content of the grape, especially anthocyanins, flavonols, and stilbenes [22,78]. Likewise, the application of this elicitor to grapevines of the $V$. labrusca species cultivated under subtropical climate also induced an improvement in the content of flavonoid and nonflavonoid compounds, such as anthocyanins, flavonols, hydroxycinnamic acids, flavanols, and stilbenes [6]. However, the effectiveness of MeJ applications to grapevines on the content of phenolic compounds in grapes depends mostly on the response of the variety and the climatic conditions of the season [22,79,80]. MeJ application to 'Mourvèdre' and 'Tempranillo' increased the grape proanthocyanidin content, but only in one of the two seasons studied, and did not affect the extractability of these compounds in the produced wines [16]. In this sense, Paladines-Quezada et al. [81] indicated that MeJ applications to 'Mourvèdre', 'Merlot', and 'Cabernet Sauvignon' grapevines caused significant changes in various structural components of the grape skins cell walls, such as phenolic compounds, proteins, and sugars. Thus, MeJ application to the grapevines increased the protein and phenol content in the grape skins cell wall of the 'Mourvèdre' and 'Cabernet Sauvignon', while in 'Merlot', it had an opposite effect. However, regardless of the climatic condi- 
tions, MeJ applications to grapevines increased the content of phenolic compounds in 'Mourvèdre' grapes, which, despite having a high amount of phenolic compounds in their grapes, are hardly extracted during winemaking [82]. Generally, MeJ applications to grapevines are performed when the grapes reach the veraison stage, at which time there is a greater distribution of nutrients and the berries begin to accumulate sugars, phenolic compounds, and other elements through the phloem. However, it has been reported that the MeJ applications performed after veraison to 'Syrah' grapevines improved the content of phenolic compounds, compared to the MeJ applications carried out just at this phenological stage [21]. Therefore, it is possible to optimize the time of MeJ application with the aim to maximize its positive effect on grape phenolic compounds at harvest, probably delaying its application until a few weeks after veraison [21]. These results are interesting since the systemic responses discussed in the previous sections can appear in periods as short as $2 \mathrm{~h}$ after elicitation $[83,84]$.

Table 1. Effects of methyl jasmonate (MeJ) applications (directly to leaves or grapes, or whole plant) to grapevines on grape flavonoids and stilbenes content.

\begin{tabular}{|c|c|c|c|}
\hline Variety & Effects of MeJ Treatments & Dosage and Timing Application & Reference \\
\hline \multirow{5}{*}{ Syrah } & $\begin{array}{l}\text { Increased trans-resveratrol content in } \\
\text { grapes 1.65-fold more than control }\end{array}$ & $\begin{array}{c}10 \mathrm{mM} \text { to grapes in three applications at } 20,16, \\
\text { and } 13 \text { days before harvest }\end{array}$ & Fernández-Marin et al. [85] \\
\hline & $\begin{array}{l}\text { Did not affect total anthocyanins (TA), } \\
\text { decreased total flavonols (TF) (9\%), and } \\
\text { increased total proanthocyanins (TP) in } \\
\text { skins }(20 \%) \text { and seeds }(15 \%)\end{array}$ & $\begin{array}{l}10 \mathrm{mM} \text { to plants in three applications at the } \\
\text { beginning of veraison and then } 3 \text { and } 6 \text { days } \\
\text { later }\end{array}$ & Gil-Muñoz et al. [79] \\
\hline & $\begin{array}{l}\text { Increased trans }(144 \%) \text { and cis-piceid } \\
(135 \%) \text { and trans-resveratrol }(354 \%) \\
\text { content in grapes in the second season }\end{array}$ & $\begin{array}{c}10 \mathrm{mM} \text { to grapes in two applications at the } \\
\text { beginning of veraison and 7-12 days after the } \\
\text { first application }\end{array}$ & Gil-Muñoz et al. [80] \\
\hline & $\begin{array}{l}\text { Increased TP content in skins in both } \\
\text { seasons }(12 \% \text { and } 5 \%) \text {, and in seed }(26 \%) \\
\text { in the second season }\end{array}$ & $\begin{array}{c}10 \mathrm{mM} \text { to grapes in two applications at the } \\
\text { beginning of veraison and 7-12 days after the } \\
\text { first application }\end{array}$ & Gil-Muñoz et al. [16] \\
\hline & $\begin{array}{l}\text { Increased TA }(26 \%) \text {, decreased TF }(13 \%) \\
\text { and TP in skins }(18 \%) \text { and seeds }(15 \%)\end{array}$ & $\begin{array}{c}10 \mathrm{mM} \text { to plants in three applications at the } \\
\text { beginning of veraison and then } 3 \text { and } 6 \text { days } \\
\text { later }\end{array}$ & Gil-Muñoz et al. [79] \\
\hline \multirow[t]{8}{*}{ Mourvèdre } & $\begin{array}{l}\text { Increased anthocyanins (13\%), stilbenes } \\
(119 \%) \text { in grapes compared to control }\end{array}$ & $\begin{array}{c}10 \mathrm{mM} \text { to grapes in three applications at } \\
\text { beginning of veraison and then } 3 \text { and } \\
6 \text { days later }\end{array}$ & Ruiz-García et al. [76] \\
\hline & $\begin{array}{c}\text { Increased the skin }(9 \% \text { and } 82 \%) \text { and } \\
\text { grape }(16 \%) \text { TA and skin TP }(34 \% \text { and } \\
31 \%) \text { content in two seasons }\end{array}$ & $\begin{array}{c}10 \mathrm{mM} \text { to plants in three applications at the } \\
\text { beginning of veraison and then } 3 \text { and } 6 \text { days } \\
\text { later }\end{array}$ & Ruiz-García et al. [74] \\
\hline & $\begin{array}{l}\text { Increased skin (132\%) and grape ( } 50 \%) \mathrm{TF} \\
\text { in the second study season }\end{array}$ & $\begin{array}{c}10 \mathrm{mM} \text { to plants in three applications at the } \\
\text { beginning of veraison and then } 3 \text { and } 6 \text { days } \\
\text { later }\end{array}$ & Ruiz-García et al. [74] \\
\hline & $\begin{array}{l}\text { Increased TA content in a first season } \\
(30 \%) \text { while decreased its content in the } \\
\text { second season }(10 \%) \text {. }\end{array}$ & $\begin{array}{l}10 \mathrm{mM} \text { to grapes in two applications at } \\
\text { veraison and } 1 \text { week later }\end{array}$ & Paladines-Quezada et al. [81] \\
\hline & Did not affect TF content in grapes & $\begin{array}{l}10 \mathrm{mM} \text { to grapes in two applications at } \\
\text { veraison and } 1 \text { week later }\end{array}$ & Paladines-Quezada et al. [81] \\
\hline & $\begin{array}{l}\text { Increased trans-resveratrol (53\%) content } \\
\text { in grapes in the second season }\end{array}$ & $\begin{array}{c}10 \mathrm{mM} \text { to grapes in two applications at the } \\
\text { beginning of veraison and 7-12 days after the } \\
\text { first application }\end{array}$ & Gil-Muñoz et al. [80] \\
\hline & $\begin{array}{l}\text { Increased TP content in skins }(25 \%) \text { and } \\
\text { seeds }(18 \%) \text { in the second season }\end{array}$ & $\begin{array}{c}10 \mathrm{mM} \text { to grapes in two applications at the } \\
\text { beginning of veraison and 7-12 days after the } \\
\text { first application }\end{array}$ & Gil-Muñoz et al. [16] \\
\hline & $\begin{array}{l}\text { Decreased TP content in skins }(17 \%) \text { and } \\
\text { seeds }(53 \%) \text { in the first season }\end{array}$ & $\begin{array}{l}10 \mathrm{mM} \text { to grapes in two applications at the } \\
\text { beginning of veraison and 7-12 days after the } \\
\text { first application }\end{array}$ & Gil-Muñoz et al. [16] \\
\hline \multirow[t]{4}{*}{ Tempranillo } & $\begin{array}{l}\text { Increased TA content ( } 25 \% \text { and } 20 \%) \\
\text { compared to control in both seasons }\end{array}$ & $\begin{array}{l}10 \mathrm{mM} \text { over the leaves in two applications at } \\
\text { veraison and one week later }\end{array}$ & Portu et al. [22] \\
\hline & $\begin{array}{l}\text { Did not affect TA, flavonols, and } \\
\text { hydroxycinnamic acids content in grapes }\end{array}$ & $\begin{array}{l}10 \mathrm{mM} \text { over the leaves in two applications at } \\
\text { veraison and one week later }\end{array}$ & Portu et al. [22] \\
\hline & $\begin{array}{l}\text { Increased total stilbenes (TS) (189\% and } \\
41 \%) \text { content compared to control in both } \\
\text { seasons }\end{array}$ & $\begin{array}{l}10 \mathrm{mM} \text { over the leaves in two applications at } \\
\text { veraison and one week later }\end{array}$ & Portu et al. [22] \\
\hline & $\begin{array}{c}\text { Increased TA ( } 23 \%) \text {, trans }(462 \%) \text {, and } \\
\text { cis-piceid }(233 \%) \text { and TS }(310 \%) \text { content in } \\
\text { grapes compared to control }\end{array}$ & $\begin{array}{l}10 \mathrm{mM} \text { over the leaves in two applications at } \\
\text { veraison and one week later }\end{array}$ & Portu et al. [23] \\
\hline
\end{tabular}


Table 1. Cont.

\begin{tabular}{|c|c|c|c|}
\hline Variety & Effects of MeJ Treatments & Dosage and Timing Application & Reference \\
\hline Graciano & $\begin{array}{c}\text { Did not affect TA, flavonols, and } \\
\text { hydroxycinnamic acids content in grapes } \\
\text { Increased the content of TS (26\%) in the } \\
\text { second season }\end{array}$ & $\begin{array}{c}10 \mathrm{mM} \text { over the leaves in two applications at } \\
\text { veraison and one week later } \\
10 \mathrm{mM} \text { over the leaves in two applications at } \\
\text { veraison and one week later }\end{array}$ & $\begin{array}{l}\text { Portu et al. [22] } \\
\text { Portu et al. [22] }\end{array}$ \\
\hline Merlot & $\begin{array}{l}\text { Increased TA }(14 \%) \text { and TP in skins }(78 \%) \\
\text { and seeds }(86 \%) \text { while decreased TF }(23 \%)\end{array}$ & $\begin{array}{c}10 \mathrm{mM} \text { to plants in three applications at the } \\
\text { beginning of veraison and then } 3 \text { and } 6 \text { days } \\
\text { later }\end{array}$ & Gil-Muñoz et al. [79] \\
\hline Grenache & $\begin{array}{c}\text { Increased TA ( } 45 \%), \mathrm{TF}(62 \%) \text {, and total } \\
\text { hydroxycinnamic acids ( } 36 \%) \text { compared to } \\
\text { control }\end{array}$ & $10 \mathrm{mM}$ to plants (no more information added) & Portu et al. [78] \\
\hline & $\begin{array}{l}\text { Increased trans and cis-piceid }(1544 \% \text { and } \\
315 \%) \text { in leaves and trans-resveratrol } \\
\text { (767\%) content in grapes }\end{array}$ & $\begin{array}{c}400 \mathrm{nmol} / \mathrm{L} \text { as vapor } 15 \text { or } 30 \text { days after } \\
\text { veraison }\end{array}$ & Larronde et al. [73] \\
\hline $\begin{array}{l}\text { Cabernet } \\
\text { Sauvignon }\end{array}$ & $\begin{array}{c}\text { Increased trans }(1804 \%) \text { and cis-piceid } \\
(253 \%) \text { and trans-resveratrol (1380\%) } \\
\text { content in leaves }\end{array}$ & $\begin{array}{c}400 \mathrm{nmol} / \mathrm{L} \text { as vapor } 15 \text { or } 30 \text { days after } \\
\text { veraison }\end{array}$ & Larronde et al. [73] \\
\hline Barbera & $\begin{array}{l}\text { Increased berry resveratrol and } \varepsilon \text {-viniferin } \\
\text { production at ripening }\end{array}$ & $\begin{array}{l}10 \mathrm{mM} \text { to grapes in three applications at fruit } \\
\text { set, veraison, and ripening ( } 45 \text { days after } \\
\text { veraison) }\end{array}$ & Vezzulli et al. [18] \\
\hline
\end{tabular}

Table 2. Effects of methyl jasmonate (MeJ) applications (directly to leaves or grapes, or whole plant) to grapevines on wine flavonoids and stilbenes content.

\begin{tabular}{|c|c|c|c|}
\hline Variety & Effects of MeJ Treatments & Dosage and Timing Application & Reference \\
\hline \multirow{6}{*}{ Mourvèdre } & $\begin{array}{l}\text { Higher content of trans and cis-piceid } \\
(220 \% \text { and } 314 \%) \text { and trans and } \\
\text { cis-resveratrol ( } 407 \% \text { and } 21 \%) \text { than } \\
\text { control samples in the first season }\end{array}$ & $\begin{array}{l}10 \mathrm{mM} \text { to grapes in two applications at } \\
\text { the beginning of veraison and 7-12 days } \\
\text { after the first application }\end{array}$ & Gil-Muñoz et al. [80] \\
\hline & $\begin{array}{l}\text { Higher content of trans-resveratrol } \\
(28 \%) \text { than control samples in the } \\
\text { second season }\end{array}$ & $\begin{array}{l}10 \mathrm{mM} \text { to grapes in two applications at } \\
\text { the beginning of veraison and 7-12 days } \\
\text { after the first application }\end{array}$ & Gil-Muñoz et al. [80] \\
\hline & $\begin{array}{c}\text { Lower total proanthocyanins }(\mathrm{TP}) \\
\text { content in a first season }(8 \%) \text { and } \\
\text { higher TP content in a second season } \\
(38 \%) \text { than control wines }\end{array}$ & $\begin{array}{l}10 \mathrm{mM} \text { to grapes in two applications at } \\
\text { the beginning of veraison and } 7-12 \text { days } \\
\text { after the first application }\end{array}$ & Gil-Muñoz et al. [16] \\
\hline & $\begin{array}{l}\text { Higher TP }(44 \%) \text {, total anthocyanins } \\
\text { (TA) }(51 \%) \text { and total flavonols (TF) } \\
\text { (24\%) content than control wines }\end{array}$ & $\begin{array}{c}10 \mathrm{mM} \text { to plants in three applications at } \\
\text { the beginning of veraison and then } 3 \text { and } \\
6 \text { days later }\end{array}$ & Gil-Muñoz et al. [79] \\
\hline & $\begin{array}{l}\text { Higher total tannins }(14 \%) \text { and TA } \\
(74 \%) \text { content than control wines in a } \\
\text { second study season }\end{array}$ & $\begin{array}{c}10 \mathrm{mM} \text { to plants in three applications at } \\
\text { the beginning of veraison and then } 3 \text { and } \\
6 \text { days later }\end{array}$ & Ruiz-Garcia et al. [74] \\
\hline & $\begin{array}{c}\text { Higher TA content in a first season } \\
(18 \%) \text { and lower TA content in a } \\
\text { second season }(29 \%) \text { than control } \\
\text { wines }\end{array}$ & $\begin{array}{l}10 \mathrm{mM} \text { to plants in three applications at } \\
\text { the beginning of veraison and then } 3 \text { and } \\
6 \text { days later }\end{array}$ & Ruiz-Garcia et al. [74] \\
\hline \multirow{4}{*}{ Tempranillo } & $\begin{array}{c}\text { Higher content of trans and cis-piceid } \\
(37 \% \text { and } 35 \%) \text { and trans-resveratrol } \\
(625 \%) \text { than control wines in a first } \\
\text { season }\end{array}$ & $\begin{array}{l}10 \mathrm{mM} \text { to grapes in two applications at } \\
\text { the beginning of veraison and } 7-12 \text { days } \\
\text { after the first application }\end{array}$ & Gil-Muñoz et al. [80] \\
\hline & $\begin{array}{l}\text { Lower content of cis-resveratrol }(80 \%) \\
\text { in a first season, and higher } \\
\text { trans-resveratrol }(37 \%) \text { content in a } \\
\text { second season than control wines }\end{array}$ & $\begin{array}{l}10 \mathrm{mM} \text { to grapes in two applications at } \\
\text { the beginning of veraison and 7-12 days } \\
\text { after the first application }\end{array}$ & Gil-Muñoz et al. [80] \\
\hline & $\begin{array}{c}\text { Higher TP }(110 \%) \text { content than } \\
\text { control wines in the second season. } \\
\text { TP content in wines was not affected } \\
\text { in the first season }\end{array}$ & $\begin{array}{l}10 \mathrm{mM} \text { to grapes in two applications at } \\
\text { the beginning of veraison and } 7-12 \text { days } \\
\text { after the first application }\end{array}$ & Gil-Muñoz et al. [16] \\
\hline & $\begin{array}{c}\text { Higher TA }(24 \%), \mathrm{TF}(39 \%) \\
\text { trans-piceid }(210 \%) \text { and total stilbenes } \\
(163 \%) \text { content than control wines }\end{array}$ & $\begin{array}{c}10 \mathrm{mM} \text { over the leaves in two } \\
\text { applications at veraison and one week } \\
\text { later }\end{array}$ & Portu et al. [23] \\
\hline
\end{tabular}


Table 2. Cont.

\begin{tabular}{|c|c|c|c|}
\hline Variety & Effects of MeJ Treatments & Dosage and Timing Application & Reference \\
\hline \multirow[b]{2}{*}{ Syrah } & $\begin{array}{l}\text { Higher TP }(8 \%) \text {, TA }(3 \%) \text { and TF } \\
(24 \%) \text { content than control wines }\end{array}$ & $\begin{array}{l}10 \mathrm{mM} \text { to plants in three applications at } \\
\text { the beginning of veraison and then } 3 \text { and } \\
6 \text { days later }\end{array}$ & Gil-Muñoz et al. [79] \\
\hline & $\begin{array}{l}\text { Higher trans-resveratrol ( } 37 \% \text { and } \\
16 \%), \varepsilon \text {-viniferin }(49 \% \text { and } 13 \%) \text { and } \\
\text { total stilbenes ( } 38 \% \text { and } 24 \% \text { ) than } \\
\text { control pressed and bottled wines }\end{array}$ & $\begin{array}{l}10 \mathrm{mM} \text { to grapes in three applications at } \\
20,16 \text {, and } 13 \text { days before harvest }\end{array}$ & Fernández-Marín et al. [85] \\
\hline Merlot & $\begin{array}{c}\text { Higher TP }(11 \%) \text { and lower TA }(2 \%) \\
\text { and TF }(8 \%) \text { content than control } \\
\text { wines }\end{array}$ & $\begin{array}{l}10 \mathrm{mM} \text { to plants in three applications at } \\
\text { the beginning of veraison and then } 3 \text { and } \\
6 \text { days later }\end{array}$ & Gil-Muñoz et al. [79] \\
\hline
\end{tabular}

Most of the reports published in this field do not support their information with genetic or enzymatic analysis that can be altered after the MeJ application; therefore, most of the conclusions are based on suggestions and do not have accurate scientific support. Future research should take into account studies about transcription factors or enzymes that are altered by the use of elicitors to know with certainty which are the metabolic pathways that are induced after their application, as have recently explored by some researchers $[67,72]$. On the other hand, it is of particular importance to know the optimal moment of the MeJ application, as has been suggested by Gómez-Plaza et al. [21], and, in this way, obtain grapes with high enological potential and bioactivity. The synthesis of biopolymeric nanoparticles based on methyl jasmonate could be an interesting alternative to improve the phenolic composition of the grapes; however, it is critical to obtain a correct synthesis and to know the new properties of the elicitor obtained after this process. Recently, the use of nanoparticles based on methyl jasmonate has been studied by Chronopoulou et al. [86], who used it to improve the synthesis of stilbenes in grapevine cell cultures and thus to suggest this treatment as a new strategy for the integrated pest and disease management. In this sense, one of the disadvantages of MeJ applications to vineyard at a commercial level is its high price per hectare; therefore, its application in nanoformulations could decrease its price because a lower dose can be used.

Global transcriptomic approaches can provide new clues on both the transcriptional cascade activated by elicitors and the possible interactions taking place when they are applied in combination [87]. The high effectiveness of cyclic oligosaccharides such as cyclodextrins in the production of trans-resveratrol in Vitis vinifera cell cultures was enhanced in the presence of MeJ [88]. This resulted in crosstalk between the signaling cascades activated by cyclodextrins and MeJ, which provoked the activation of additional regulatory pathways involving the upregulation of MYB15, NAC (term derived from three genes sharing the NAC domain, i.e., no apical meristem (NAM), Arabidopsis transcription activator factor $\frac{1}{2}$ (ATAF 1/2) and cup-shaped cotyledon (CUC2)) and WRKY transcription factors, protein kinases, and calcium signal transducers [87]. Crosstalk between both elicitors-induced signaling pathway provokes an intensification of these responses resulting in greater trans-resveratrol production in cell cultures $[87,88]$. Similar interactions were exposed by Ismail et al. [89], who reported that salt stress signaling acts as a default pathway whose readout is modulated by a parallel signal chain triggered by biotic factors downstream of jasmonate signaling. To our knowledge, only one study has been carried out at the field level in relation to the combined effect of plant hormones in the synthesis of phenolic compounds in grapes. In this study, MeJ and benzothiadiazole (BHT) applications to 'Mourvèdre' grapevines increased the concentration of several anthocyanins, but it did not affect the content of flavonols and flavanols in grapes, compared to untreated grapevines [75]. In this study, MeJ+BHT treatment was not compared with the individual application of these plant hormones, and molecular analysis was not carried out to evaluate crosstalk effects between them. 


\section{Conclusions}

Phenolic compounds play a key role in grape and wine quality due to their contribution to sensory characteristics of grapes and wines such as color, astringency, and bitterness. During the last years, the study of the application of elicitors in viticulture has increased due to its positive effects in the synthesis of phenolic compounds in grapes, especially anthocyanins, flavonols, flavanols, and stilbenes. In this sense, elicitors can play a key role in pest and disease management, improving grape quality. Methyl jasmonate (MeJ) is the most widely used elicitor in these studies due to its significant contribution to the grape's flavonoid and stilbene contents. Some researchers have reported that MeJ applications to grapevines improve the content of most of the families of phenolic compounds in grapes and wines. However, the effectiveness of this treatment depends on the variety and season factors, which may affect the extractability of these compounds in winemaking. Future research should be carried out in order to understand the resistance mechanisms involved in the elicitation mostly at field conditions, as well as the optimal time of MeJ application, including crosstalk with other plant hormones with the aim to obtain grapes with high oenological potential. On the other hand, the synthesis of nanoparticles based on MeJ could be an interesting alternative to improve the flavonoid and stilbene contents in grapes. However, it is important to quantify the degree of toxicity that nanoparticles can leave in the environment. Finally, despite the fact that this elicitor triggers interesting adaptation mechanisms in grapevines, we do not recommend its use as a phytosanitary product because grapevines have a high susceptibility to cryptogamic diseases.

Author Contributions: Conceptualization, G.G.-G., N.M. and N.V.-V.; investigation, G.G.-G., R.M.C., I.D.-G., N.M. and N.V.-V.; writing—original draft preparation, G.G.-G. and N.M.; writing-review and editing, I.D.-G., N.M. and N.V.-V.; supervision, G.G.-G., I.D.-G., N.M. and N.V.-V. All authors have read and agreed to the published version of the manuscript.

Funding: This research received no external funding.

Institutional Review Board Statement: Not applicable.

Informed Consent Statement: Not applicable.

Conflicts of Interest: The authors declare no conflict of interest.

\section{References}

1. Gismondi, A.; Di Marco, G.; Martini, F.; Sarti, L.; Crespan, M.; Martínez-Labarga, C.; Rickards, O.; Canini, A. Grapevine carpological remains revealed the existence of a Neolithic domesticated Vitis vinifera L. specimen containing ancient DNA partially preserved in modern ecotypes. J. Archaeol. Sci. 2016, 69, 75-84. [CrossRef]

2. Liang, Z.; Yang, Y.; Cheng, L.; Zhong, G.Y. Polyphenolic composition and content in the ripe berries of wild Vitis species. Food Chem. 2012, 132, 730-738. [CrossRef]

3. Fraga, C.G.; Croft, K.D.; Kennedy, D.O.; Tomás-Barberán, F.A. The effects of polyphenols and other bioactives on human health. Food Funct. 2019, 10, 514-528. [CrossRef]

4. Zúñiga-López, M.C.; Felipe Laurie, V.; Barriga-González, G.; Folch-Cano, C.; Fuentes, J.; Agosín, E.; Olea-Azar, C. Chemical and biological properties of phenolics in wine: Analytical determinations and health benefits. Curr. Org. Chem. 2017, 21, 357-367. [CrossRef]

5. Ferrer-Gallego, R.; Hernández-Hierro, J.M.; Rivas-Gonzalo, J.C.; Escribano-Bailón, M.T. Sensory evaluation of bitterness and astringency sub-qualities of wine phenolic compounds: Synergistic effect and modulation by aromas. Food Res. Int. 2014, 62, 1100-1107. [CrossRef]

6. Moro, L.; Da Ros, A.; da Mota, R.V.; Purgatto, E.; Mattivi, F.; Arapitsas, P. LC-MS untargeted approach showed that methyl jasmonate application on Vitis labrusca L. grapes increases phenolics at subtropical Brazilian regions. Metabolomics 2020, 16, 1-12. [CrossRef]

7. Pérez-Lamela, C.; García-Falcón, M.S.; Simal-Gándara, J.; Orriols-Fernández, I. Influence of grape variety, vine system and enological treatments on the colour stability of young red wines. Food Chem. 2007, 101, 601-606. [CrossRef]

8. Kyraleou, M.; Kotseridis, Y.; Koundouras, S.; Chira, K.; Teissedre, P.L.; Kallithraka, S. Effect of irrigation regime on perceived astringency and proanthocyanidin composition of skins and seeds of Vitis vinifera L. cv. Syrah grapes under semiarid conditions. Food Chem. 2016, 203, 292-300. [CrossRef]

9. Carrasco-Quiroz, M.; Martínez-Gil, A.M.; Gutiérrez-Gamboa, G.; Moreno-Simunovic, Y. Effect of rootstocks on volatile composition of Merlot wines. J. Sci. Food Agric. 2020. [CrossRef] [PubMed] 
10. Gutiérrez-Gamboa, G.; Gómez-Plaza, E.; Bautista-Ortín, A.B.; Garde-Cerdán, T.; Moreno-Simunovic, Y.; Martínez-Gil, A.M. Rootstock effects on grape anthocyanins, skin and seed proanthocyanidins and wine color and phenolic compounds from Vitis vinifera L. Merlot grapevines. J. Sci. Food Agric. 2019, 99, 2846-2854. [CrossRef]

11. Peña-Neira, A.; Cáceres, A.; Pastenes, C. Low molecular weight phenolic and anthocyanin composition of grape skins from cv. Syrah (Vitis vinifera L.) in the Maipo Valley (Chile): Effect of clusters thinning and vineyard yield. Food Sci. Technol. Int. 2007, 13, 153-158. [CrossRef]

12. Vergara, A.E.; Díaz, K.; Carvajal, R.; Espinoza, L.; Alcalde, J.A.; Pérez-Donoso, A.G. Exogenous applications of brassinosteroids improve color of red table grape (Vitis vinifera L. Cv. "Redglobe") berries. Front. Plant Sci. 2018, 9, 363. [CrossRef] [PubMed]

13. Balint, G.; Reynolds, A.G. Impact of exogenous Abscisic acid on vine physiology and grape composition of cabernet sauvignon. Am. J. Enol. Vitic. 2013, 64, 74-87. [CrossRef]

14. Berli, F.; Fanzone, M.; Piccoli, P.; Bottini, R. Solar UV-B and ABA are involved in phenol metabolism of Vitis vinifera L. Increasing biosynthesis of berry skin polyphenols. J. Agric. Food Chem. 2011, 59, 4874-4884. [CrossRef]

15. Koyama, R.; Roberto, S.R.; de Souza, R.T.; Borges, W.F.S.; Anderson, M.; Waterhouse, A.L.; Cantu, D.; Fidelibus, M.W.; BlancoUlate, B. Exogenous abscisic acid promotes anthocyanin biosynthesis and increased expression of flavonoid synthesis genes in Vitis vinifera $\times$ Vitis labrusca table grapes in a Subtropical Region. Front. Plant Sci. 2018, 9, 323. [CrossRef] [PubMed]

16. Gil-Muñoz, R.; Fernández-Fernández, J.I.; Portu, J.; Garde-Cerdán, T. Methyl jasmonate: Effect on proanthocyanidin content in Monastrell and Tempranillo grapes and wines. Eur. Food Res. Technol. 2018, 244, 611-621. [CrossRef]

17. Flamini, R.; Mattivi, F.; De Rosso, M.; Arapitsas, P.; Bavaresco, L. Advanced knowledge of three important classes of grape phenolics: Anthocyanins, stilbenes and flavonols. Int. J. Mol. Sci. 2013, 14, 19651-19669. [CrossRef] [PubMed]

18. Vezzulli, S.; Civardi, S.; Ferrari, F.; Bavaresco, L. Methyl jasmonate treatment as a trigger of resveratrol synthesis in cultivated grapevine. Am. J. Enol. Vitic. 2007, 58, 530-533.

19. Balbontín, C.; Gutiérrez, C.; Wolff, M.; Figueroa, C.R. Effect of abscisic acid and methyl jasmonate preharvest applications on fruit quality and cracking tolerance of sweet cherry. Chil. J. Agric. Res. 2018, 78, 438-446. [CrossRef]

20. Per, T.S.; Khan, M.I.R.; Anjum, N.A.; Masood, A.; Hussain, S.J.; Khan, N.A. Jasmonates in plants under abiotic stresses: Crosstalk with other phytohormones matters. Environ. Exp. Bot. 2018, 145, 104-120.

21. Gómez-Plaza, E.; Bautista-Ortín, A.B.; Ruiz-García, Y.; Fernández-Fernández, J.I.; Gil-Muñoz, R. Effect of elicitors on the evolution of grape phenolic compounds during the ripening period. J. Sci. Food Agric. 2017, 97, 977-983. [CrossRef] [PubMed]

22. Portu, J.; López, R.; Santamaría, P.; Garde-Cerdán, T. Methyl jasmonate treatment to increase grape and wine phenolic content in Tempranillo and Graciano varieties during two growing seasons. Sci. Hortic. 2018, 240, 378-386. [CrossRef]

23. Portu, J.; Santamaría, P.; López-Alfaro, I.; López, R.; Garde-Cerdán, T. Methyl jasmonate foliar application to tempranillo vineyard improved grape and wine phenolic content. J. Agric. Food Chem. 2015, 63, 2328-2337. [CrossRef]

24. Buchanan, B.B.; Gruissem, W.; Jones, R.L. Biochemistry and Molecular Biology of Plants, 2nd ed.; Wiley: Hoboken, NJ, USA, 2015.

25. Repka, V. Elicitor-stimulated induction of defense mechanisms and defense gene activation in grapevine cell suspension cultures. Biol. Plant. 2001, 44, 555-565. [CrossRef]

26. Ford, C.M.; Boss, P.K.; Hæj, P.B. Cloning and characterization of Vitis vinifera UDP-glucose. Flavonoid 3-O-Glucosyltransferase, a homologue of the enzyme encoded by the maize Bronze-1 locus that may primarily serve to glucosylate anthocyanidins in vivo. $J$. Biol. Chem. 1998, 273, 9224-9233. [CrossRef]

27. Downey, M.O.; Dokoozlian, N.K.; Krstic, M.P. Cultural practice and environmental impacts on the flavonoid composition of grapes and wine: A review of recent research. Am. J. Enol. Vitic. 2006, 57, 257-268.

28. Waterhouse, A.L.; Sacks, G.L.; Jeffery, D.W. Grape genetics, chemistry, and breeding. In Understanding Wine Chemistry; John Wiley \& Sons: Hoboken, NJ, USA, 2016; pp. 2-5. [CrossRef]

29. Gonzalo-Diago, A.; Dizy, M.; Fernández-Zurbano, P. Contribution of low molecular weight phenols to bitter taste and mouthfeel properties in red wines. Food Chem. 2014, 154, 187-198. [CrossRef]

30. Downey, M.O.; Harvey, J.S.; Robinson, S.P. Synthesis of flavonols and expression of flavonol synthase genes in the developing grape berries of Shiraz and Chardonnay (Vitis vinifera L.). Aust. J. Grape Wine Res. 2003, 9, 110-121. [CrossRef]

31. Matus, J.T.; Loyola, R.; Vega, A.; Peña-Neira, A.; Bordeu, E.; Arce-Johnson, P.; Alcalde, J.A. Post-veraison sunlight exposure induces MYB-mediated transcriptional regulation of anthocyanin and flavonol synthesis in berry skins of Vitis vinifera. J. Exp. Bot. 2009, 60, 853-867. [CrossRef]

32. Kennedy, J.A.; Saucier, C.; Glories, Y. Grape and wine phenolics: History and perspective. Am. J. Enol. Vitic. 2006, 57, 239-248.

33. Villalobos-González, L.; Peña-Neira, A.; Ibáñez, F.; Pastenes, C. Long-term effects of abscisic acid (ABA) on the grape berry phenylpropanoid pathway: Gene expression and metabolite content. Plant Physiol. Biochem. 2016, 105, 213-223. [CrossRef]

34. Kennedy, J.A.; Hayasaka, Y.; Vidal, S.; Waters, E.J.; Jones, G.P. Composition of grape skin proanthocyanidins at different stages of berry development. J. Agric. Food Chem. 2001, 49, 5348-5355. [CrossRef] [PubMed]

35. Sirerol, J.A.; Rodríguez, M.L.; Mena, S.; Asensi, M.A.; Estrela, J.M.; Ortega, A.L. Role of natural stilbenes in the prevention of cancer. Oxid. Med. Cell. Longev. 2016, 3128951. [CrossRef] [PubMed]

36. Hasan, M.M.; Cha, M.; Bajpai, V.K.; Baek, K.H. Production of a major stilbene phytoalexin, resveratrol in peanut (Arachis hypogaea) and peanut products: A mini review. Rev. Env. Sci. Biotechnol. 2013, 12, 209-221. [CrossRef]

37. Jeandet, P.; Sbaghi, M.; Bessis, R.; Meunier, P. The potential relationship of stilbene (resveratrol) synthesis to anthocyanin content in grape berry skins. Vitis 1995, 34, 91-94. [CrossRef] 
38. Huang, H.; Liu, B.; Liu, L.; Song, S. Jasmonate action in plant growth and development. J. Exp. Bot. 2017, 68, 1349-1359. [CrossRef] [PubMed]

39. Cheong, J.J.; Choi, Y. Do Methyl jasmonate as a vital substance in plants. Trends Genet. 2003, 19, 409-413. [CrossRef]

40. Worrall, D.; Holroyd, G.H.; Moore, J.P.; Glowacz, M.; Croft, P.; Taylor, J.E.; Paul, N.D.; Roberts, M.R. Treating seeds with activators of plant defence generates long-lasting priming of resistance to pests and pathogens. New Phytol. 2012, 193, 770-778. [CrossRef]

41. Rasmann, S.; De Vos, M.; Casteel, C.L.; Tian, D.; Halitschke, R.; Sun, J.Y.; Agrawal, A.A.; Felton, G.W.; Jander, G. Herbivory in the previous generation primes plants for enhanced insect resistance. Plant Physiol. 2012, 158, 854-863. [CrossRef]

42. Gutiérrez-Gamboa, G.; Portu, J.; Santamaría, P.; López, R.; Garde-Cerdán, T. Effects on grape amino acid concentration through foliar application of three different elicitors. Food Res. Int. 2017, 99, 688-692. [CrossRef]

43. Imran, Q.M.; Yun, B.W. Pathogen-induced Defense Strategies in Plants. J. Crop Sci. Biotechnol. 2020, 23, 97-105. [CrossRef]

44. Miao, X.Y.; Qu, H.P.; Han, Y.L.; He, C.F.; Qiu, D.W.; Cheng, Z.W. The protein elicitor Hrip1 enhances resistance to insects and early bolting and flowering in Arabidopsis thaliana. PLoS ONE 2019, 14, e0216082. [CrossRef] [PubMed]

45. Wang, K.; Guo, Q.; Froehlich, J.E.; Hersh, H.L.; Zienkiewicz, A.; Howe, G.A.; Benning, C. Two abscisic acid-responsive plastid lipase genes involved in jasmonic acid biosynthesis in Arabidopsis thaliana. Plant Cell 2018, 30, 1006-1022. [CrossRef]

46. Staswick, P.E.; Tiryaki, I. The oxylipin signal jasmonic acid is activated by an enzyme that conjugate it to isoleucine in Arabidopsis W inside box sign. Plant Cell 2004, 16, 2117-2127. [CrossRef] [PubMed]

47. Van Loon, L.C.; Bakker, P.A.H.M.; Pieterse, C.M.J. Systemic resistance induced by rhizosphere bacteria. Annu. Rev. Phytopathol. 1998, 36, 453-483. [CrossRef]

48. Ryu, C.M.; Murphy, J.F.; Mysore, K.S.; Kloepper, J.W. Plant growth-promoting rhizobacteria systemically protect Arabidopsis thaliana against Cucumber mosaic virus by a salicylic acid and NPR1-independent and jasmonic acid-dependent signaling pathway. Plant J. 2004, 39, 381-392. [CrossRef]

49. Berrocal-Lobo, M.; Molina, A. Ethylene response factor 1 mediates Arabidopsis resistance to the soilborne fungus Fusarium oxysporum. Mol. Plant Microbe Interact. 2004, 17, 763-770. [CrossRef]

50. Suza, W.P.; Staswick, P.E. The role of JAR1 in Jasmonoyl-1-isoleucine production during Arabidopsis wound response. Planta 2008, 227, 1221-1232. [CrossRef]

51. Lorenzo, O.; Chico, J.M.; Sánchez-Serrano, J.J.; Solano, R. JASMONATE-INSENSITIVE1 encodes a MYC transcription factor essential to discriminate between different jasmonate-regulated defense responses in arabidopsis. Plant Cell 2004, 16, 1938-1950. [CrossRef]

52. Pauwels, L.; Barbero, G.F.; Geerinck, J.; Tilleman, S.; Grunewald, W.; Pérez, A.C.; Chico, J.M.; Bossche, R.V.; Sewell, J.; Gil, E.; et al. NINJA connects the co-repressor TOPLESS to jasmonate signalling. Nature 2010, 464, 788-791. [CrossRef]

53. Martin-Arevalillo, R.; Nanao, M.H.; Larrieu, A.; Vinos-Poyo, T.; Mast, D.; Galvan-Ampudia, C.; Brunoud, G.; Vernoux, T.; Dumas, R.; Parcy, F. Structure of the Arabidopsis TOPLESS corepressor provides insight into the evolution of transcriptional repression. Proc. Natl. Acad. Sci. USA 2017, 114, 8107-8112. [CrossRef]

54. Szemenyei, H.; Hannon, M.; Long, J.A. TOPLESS mediates auxin-dependent transcriptional repression during Arabidopsis embryogenesis. Science 2008, 319, 1384-1386. [CrossRef]

55. Santner, A.; Estelle, M. The ubiquitin-proteasome system regulates plant hormone signaling. Plant J. 2010, 61, 1029-1040. [CrossRef]

56. Wiesel, L.; Newton, A.C.; Elliott, I.; Booty, D.; Gilroy, E.M.; Birch, P.R.J.; Hein, I. Molecular effects of resistance elicitors from biological origin and their potential for crop protection. Front. Plant Sci. 2014, 5, 655. [CrossRef]

57. Pastor, V.; Luna, E.; Mauch-Mani, B.; Ton, J.; Flors, V. Primed plants do not forget. Env. Exp. Bot. 2013, 94, 46-56. [CrossRef]

58. Walters, D.; Heil, M. Costs and trade-offs associated with induced resistance. Physiol. Mol. Plant Pathol. 2007, 71, 3-17. [CrossRef]

59. Zhou, X.; Jiang, Y.; Yu, D. WRKY22 transcription factor mediates dark-induced leaf senescence in Arabidopsis. Mol. Cells 2011, 31, 303-313. [CrossRef] [PubMed]

60. Conrath, U. Molecular aspects of defence priming. Trends Plant Sci. 2011, 16, 524-531. [CrossRef]

61. Jaskiewicz, M.; Conrath, U.; Peterhälnsel, C. Chromatin modification acts as a memory for systemic acquired resistance in the plant stress response. Embo. Rep. 2011, 12, 50-55. [CrossRef]

62. Chen, Z.; Zheng, Z.; Huang, J.; Lai, Z.; Fan, B. Biosynthesis of salicylic acid in plants. Plant Signal. Behav. 2009, 4, 493-496. [CrossRef]

63. Iriti, M.; Rossoni, M.; Borgo, M.; Ferrara, L.; Faoro, F. Induction of resistance to gray mold with benzothiadiazole modifies amino acid profile and increases proanthocyanidins in grape: Primary versus secondary metabolism. J. Agric. Food Chem. 2005, 53, 9133-9139. [CrossRef] [PubMed]

64. Ruiz-García, Y.; Gómez-Plaza, E. Elicitors: A tool for improving fruit phenolic content. Agriculture 2013, 3, 33-52. [CrossRef]

65. Conrath, U.; Beckers, G.J.M.; Flors, V.; García-Agustín, P.; Jakab, G.; Mauch, F.; Newman, M.A.; Pieterse, C.M.J.; Poinssot, B.; Pozo, M.J.; et al. Priming: Getting ready for battle. Mol. Plant Microbe Interact. 2006, 19, 1062-1071. [CrossRef]

66. Kohler, A.; Schwindling, S.; Conrath, U. Benzothiadiazole-induced priming for potentiated responses to pathogen infection, wounding, and infiltration of water into leaves requires the NPR1/NIM1 gene in Arabidopsis. Plant Physiol. 2002, 128, $1046-1056$. [CrossRef] 
67. Frioni, T.; Tombesi, S.; Quaglia, M.; Calderini, O.; Moretti, C.; Poni, S.; Gatti, M.; Moncalvo, A.; Sabbatini, P.; Berrìos, J.G.; et al. Metabolic and transcriptional changes associated with the use of Ascophyllum nodosum extracts as tools to improve the quality of wine grapes (Vitis vinifera cv. Sangiovese) and their tolerance to biotic stress. J. Sci. Food Agric. 2019, 99, 6350-6363. [CrossRef]

68. Wang, Q.; Zhang, Y.; Gao, M.; Jiao, C.; Wang, X. Identification and expression analysis of a pathogenresponsive PR-1 gene from Chinese wild Vitis quinquangularis. Afr. J. Biotechnol. 2013, 10, 17062-17069.

69. Martinez-Esteso, M.J.; Sellés-Marchart, S.; Vera-Urbina, J.C.; Pedreño, M.A.; Bru-Martinez, R. Changes of defense proteins in the extracellular proteome of grapevine (Vitis vinifera cv. Gamay) cell cultures in response to elicitors. J. Proteom. 2009, 73, 331-341. [CrossRef]

70. Belchí-Navarro, S.; Almagro, L.; Bru-Martínez, R.; Pedreño, M.A. Changes in the secretome of Vitis vinifera cv. Monastrell cell cultures treated with cyclodextrins and methyl jasmonate. Plant Physiol. Biochem. 2019, 135, 520-527. [CrossRef]

71. Gutiérrez-Gamboa, G.; Romanazzi, G.; Garde-Cerdán, T.; Pérez-Álvarez, E.P. A review of the use of biostimulants in the vineyard for improved grape and wine quality: Effects on prevention of grapevine diseases. J. Sci. Food Agric. 2019, 99, 1001-1009. [CrossRef] [PubMed]

72. D'Onofrio, C.; Matarese, F.; Cuzzola, A. Effect of methyl jasmonate on the aroma of Sangiovese grapes and wines. Food Chem. 2018, 242, 352-361. [CrossRef]

73. Larronde, F.; Gaudillère, J.P.; Krisa, S.; Decendit, A.; Deffieux, G.; Mérillon, J.M. Airborne methyl jasmonate induces stilbene accumulation in leaves and berries of grapevine plants. Am. J. Enol. Vitic. 2003, 54, 63-66.

74. Ruiz-García, Y.; Romero-Cascales, I.; Gil-Muñoz, R.; Fernández-Fernández, J.I.; López-Roca, J.M.; Gómez-Plaza, E. Improving grape phenolic content and wine chromatic characteristics through the use of two different elicitors: Methyl jasmonate versus benzothiadiazole. J. Agric. Food Chem. 2012, 60, 1283-1290. [CrossRef] [PubMed]

75. Ruiz-García, Y.; Gil-Muñoz, R.; López-Roca, J.M.; Martínez-Cutillas, A.; Romero-Cascales, I.; Gómez-Plaza, E. Increasing the phenolic compound content of grapes by preharvest application of abcisic acid and a combination of methyl jasmonate and benzothiadiazole. J. Agric. Food Chem. 2013, 61, 3978-3983. [CrossRef]

76. Ruiz-García, Y.; Romero-Cascales, I.; Bautista-Ortín, A.B.; Gil-Muñoz, R.; Martínez-Cutillas, A.; Gómez-Plaza, E. Increasing bioactive phenolic compounds in grapes: Response of six monastrell grape clones to benzothiadiazole and methyl jasmonate treatments. Am. J. Enol. Vitic. 2013, 64, 459-465. [CrossRef]

77. Portu, J.; López, R.; Baroja, E.; Santamaría, P.; Garde-Cerdán, T. Improvement of grape and wine phenolic content by foliar application to grapevine of three different elicitors: Methyl jasmonate, chitosan, and yeast extract. Food Chem. 2016, 201, $213-221$. [CrossRef]

78. Portu, J.; López, R.; Santamaría, P.; Garde-Cerdán, T. Elicitation with methyl jasmonate supported by precursor feeding with phenylalanine: Effect on Garnacha grape phenolic content. Food Chem. 2017, 237, 416-422. [CrossRef]

79. Gil-Muñoz, R.; Bautista-Ortín, A.B.; Ruiz-García, Y.; Fernández-Fernández, J.I.; Gómez-Plaza, E. Improving phenolic and chromatic characteristics of Monastrell, Merlot and Syrah wines by using methyl jasmonate and benzothiadiazole. Oeno One 2017, 51, 17-27. [CrossRef]

80. Gil-Muñoz, R.; Fernández-Fernández, J.I.; Crespo-Villegas, O.; Garde-Cerdán, T. Elicitors used as a tool to increase stilbenes in grapes and wines. Food Res. Int. 2017, 98, 34-39. [CrossRef]

81. Paladines-Quezada, D.F.; Moreno-Olivares, J.D.; Fernández-Fernández, J.I.; Bautista-Ortín, A.B.; Gil-Muñoz, R. Influence of methyl jasmonate and benzothiadiazole on the composition of grape skin cell walls and wines. Food Chem. 2019, 277, 691-697. [CrossRef] [PubMed]

82. Paladines-Quezada, D.F.; Moreno-Olivares, J.D.; Fernández-Fernández, J.I.; Bleda-Sánchez, J.A.; Martínez-Moreno, A.; GilMuñoz, R. Elicitors and pre-fermentative cold maceration: Effects on polyphenol concentration in monastrell grapes and wines. Biomolecules 2019, 9, 671. [CrossRef]

83. Vallad, G.E.; Goodman, R.M. Systemic acquired resistance and induced systemic resistance in conventional agriculture. Crop Sci. 2004, 44, 1920-1934. [CrossRef]

84. Feys, B.J.; Moisan, L.J.; Newman, M.A.; Parker, J.E. Direct interaction between the Arabidopsis disease resistance signaling proteins, EDS1 and PAD4. EMBO J. 2001, 20, 5400-5411. [CrossRef]

85. Fernández-Marín, M.I.; Puertas, B.; Guerrero, R.F.; García-Parrilla, M.C.; Cantos-Villar, E. Preharvest methyl Jasmonate and postharvest UVC treatments: Increasing stilbenes in wine. J. Food Sci. 2014, 79, C310-C317. [CrossRef] [PubMed]

86. Chronopoulou, L.; Donati, L.; Bramosanti, M.; Rosciani, R.; Palocci, C.; Pasqua, G.; Valletta, A. Microfluidic synthesis of methyl jasmonate-loaded PLGA nanocarriers as a new strategy to improve natural defenses in Vitis vinifera. Sci. Rep. 2019, 9, 1-9. [CrossRef] [PubMed]

87. Almagro, L.; Carbonell-Bejerano, P.; Belchí-Navarro, S.; Bru, R.; Martínez-Zapater, J.M.; Lijavetzky, D.; Pedreño, M.A. Dissecting the transcriptional response to elicitors in Vitis vinifera cells. PLoS ONE 2014, 9, e109777. [CrossRef]

88. Belchí-Navarro, S.; Almagro, L.; Lijavetzky, D.; Bru, R.; Pedreño, M.A. Enhanced extracellular production of trans-resveratrol in Vitis vinifera suspension cultured cells by using cyclodextrins and methyl jasmonate. Plant Cell Rep. 2012, 31, 81-89. [CrossRef] [PubMed]

89. Ismail, A.; Riemann, M.; Nick, P. The jasmonate pathway mediates salt tolerance in grapevines. J. Exp. Bot. 2012, 63, 2127-2139. [CrossRef] 